Volume 4 Nomor 2 Ed. Desember 2018 : page 218-241

p-ISSN: $2460-805 \mathrm{X}$ e-ISSN : 2550-0295

DOI : $10.24252 /$ iqtisaduna.v4i2.6962

\title{
Mengungkap Aspek Sedekah dalam Transaksi Mangpaindan Doi pada Masyarakat Lunjen Enrekang
}

\author{
Andi Suwandi Putra Suaib', M. Wahyuddin Abdullah², Muslimin Kara3 \\ Fakultas Ekonomi dan Bisnis Islam UIN Alauddin Makassar \\ Jalan HM Yasin Limpo No.36, Samata-Gowa \\ E-mail : andisuwandio45@gmail.com¹, tosir_wahyu@yahoo.com² ${ }^{2}$,muslimin_kara@yahoo.co.id3
}

Diterima: 23 November 2018; Direvisi: 5 Desember 2018; Diterbitkan: 22 Desember 2018

\begin{abstract}
Abstrak,
Fokus penelitian ini yakni praktik transaksi mangpaindan doi dan aspek sedekah dalam transaksi tersebut. Penelitian ini menggunakan paradigma kualitatif dengan pendekatan fenomenalogi. Adapun pengujian keabsahan data menggunakan teknik triangulasi data dan triangulasi teori untuk meningkatkan validitas dan reabilitas data. Hasil penelitian ini yakni (1) Mekanisme transaksi mangpaindan doi yang dilakukan individu masyarakat Lunjen tidak memiliki saksi, tidak ada bentuk tertulis, dan tidak ada perjanjian tempo pengembalian. (2) Inflasi uang pada transaksi mangpaindan doi terjadi antara jenjang waktu peminjaman dan pembayaran utang tersebut. (3) Hasil perhitungan sedekah qardh yang diperoleh menyatakan bahwa setiap muqridl memberikan sedekah qardh dan juga muqtaridl memperoleh sebaliknya. Transaksi mangpaindan doi memiliki nilai tambah syariah (shari'ah value added) seperti nilai tambah ekonomi pada aspek sedekah dari pengurangan nilai (inflasi), nilai tambah mental pada rasa altruistik dan juga nilai tambah spritual yakni rasa ikhlas dan rasa kehadiran Tuhan.
\end{abstract}

Kata Kunci: Utang Piutang, Inflasi, Mangpaindan Doi, Sedekah, Nilai Tambah Syariah

\section{Abstract,}

The focus of this research is the practice of transaction and doi and aspects of charity in the transaction. This study uses a qualitative paradigm with a phenomenal approach. The data validity testing uses data triangulation techniques and theory triangulation to improve data validity and reliability. The results of this study are (1) the mechanism of transactions that are carried out and carried out by individual Lunjen people has no witnesses, no written form, and no return agreement. (2) Money inflation in other transactions and transactions occurs between the lending time and payment of the debt. (3) The results of the qardh alms calculation obtained state that each muqridl gives alms qardh and also muqtaridl obtains the opposite. Transactions and doi have sharia added value (shari'ah value added) such as economic value added to the charity aspect of value reduction (inflation), mental added value to altruistic feelings and spiritual added value, namely sincerity and a sense of God's presence

Keywords: Debt Receivables, Inflation, Mangpaindan Doi, Almsgiving, Added Value of Sharia 


\section{PENDAHULUAN}

Utang piutang dalam konsep Islam merupakan transaksi yang mengandung nilai tolong menolong (ta'awun). Utang piutang disebut sebagai ibadah sosial karena memiliki nilai terutama guna membantu antar sesama yang tidak mampu secara ekonomi atau sedang membutuhkan. Transaksi utang piutang pada dasarnya terlepas dari unsur komersial dan usaha yang berorientasi pada keuntungan (Ramdansyah, 2016). Objek transaksi utang piutang pada umumnya menggunakan uang, karena uang dapat dipergunakan dalam segala transaksi ekonomi. Perlu diketahui bahwa jenis uang yang sekarang digunakan sebagai alat tukar yakni uang fiat (fiat money). Fiat money adalah penggunaan uang berbasis kertas yang di terbitkan oleh institusi moneter di suatu negara tanpa disokong logam mulia. Pada sistem ini uang terus diciptakan sehingga tumbuh secara eksponensial. Kondisi ini mengakibatkan ketidakseimbangan antar sektor riil dan moneter, yang mengakibatkan inflasi (Nursyamsiah, 2018).

Inflasi secara sederhana sama dengan berkurangnya nilau uang (fiat money). Di Indonesia inflasi merupakan fenomena yang selalu terjadi setiap tahunnya. Akan tetapi beberapa tahun terakhir laju inflasi di Indonesia telah mampu di kendalikan oleh pemerintah dan otoritas terkait. Dari Asumsi dasar ekonomi makro APBN 2018 oleh Kementrian Keuangan, realisasi inflasi sampai dengan September 2017 yakni 3,7\% dan tahun 2018 diperkirakan laju inflasi kisaran 3,5\% (Kemenkeu, 2018).

Ketidakstabilan nilai uang memberikan dampak dalam perekonomian, termasuk pada transaksi utang piutang. Pemahaman masyarakat sangat beragaman menanggapi praktik utang piutang karena terjadi ketidakstabilan nilai uang, diantaranya Indeksasi yakni penambahan uang yang dikembalikan debitur dan juga utang piutang menggunakan standar barang semisal emas. Kedua praktik tersebut dianggap sangat rasional dan memenuhi rasa keadilan. Akan tetapi para Fukaha berpendapat bahwa utang piutang wajib dikembalikan sesuai dengan jumlah penerimaan sewaktu mengadakan akad tanpa menambah atau menguranginya, karena tambahan kepada pihak muqtaridl dapat memancing pernyataan adanya riba. Riba merupakan sesuatu yang jelas dilarang dalam ajaran Islam (Zainuddin, 2010). Sebagaimana firman Allah SWT. dalam QS. Al-Baqarah/2: 278-279 yang artinya:

Wahai orang-orang yang beriman! bertakwalah kepada Allah dan tinggalkan sisa Riba (yang belum dipungut) jika kamu orang-orang yang beriman. Maka jika kamu tidak melaksanakannya, Maka umumkanlah perang dari Allah dan Rasul-Nya. Namun, jika kamu bertaubat, Maka bagimu pokok hartamu. kamu tidak berbuat zalim (merugikan) dan tidak dizalimi (dirugikan).

Penjelasan sebelumnya mengisyaratkan bahwa dalam transaksi utang piutang menggunakan uang (fiat money) dapat menimbulkan ketidakadilan karena terjadi penurunan 
nilai uang (inflasi) saat pengembalian utang. Pandangan tersebut semestinya di analisis secara mendalam karena dalam ajaran Islam utang piutang hakikatnya mengandung nilai tolong menolong (ta'awun) dan terlepas dari orientasi keuntungan. Hal demikian sesuai dengan transaksi utang piutang yang dipraktikan masyarakat Lunjen Enrekang yang disebut mangpaindan doi.

Transaksi mangpaindan doi terjadi jika ada keluarga atau masyarakat yang membutuhkan uang secara mendadak kemudian meminta pinjaman uang kepada individu masyarakat ataupun lembaga sosial seperti bendahara masjid. Objek transaksi mangpaindan doi berupa uang, yang kemudian akan dipergunakan peminjam (debitur) untuk keperluan yang mendesak. Keadaan tersebut menandakan uang yang dipinjamkan akan mengalir (flow) karena dipergunakan oleh debitur. Dengan mengalir atau beredarnya uang tersebut maka akan menghasilkan nilai tambah (value added) bagi debitur maupun kreditur.

Selain itu, dalam transaksi mangpaindan doi terlepas dari praktik riba karena pengembalian pinjaman dari debitur ke kreditur sesuai padanannya (nominal yang sama saat transaksi diawal). Jadi, secara tidak langsung dalam transaksi mangpaindan doi terdapat pula aspek sedekah didalamnya. Sesuai dengan Hadis Rasulullah SAW yang artinya:

"setiap (memberi) hutang adalah (bernilai) sedekah". (HR al-Thabrani dan alBaihaqi)

Upaya penelitian nantinya, dapat memberikan pengetahuan dan pemahaman bagi masyarakat khususnya di desa Lunjen, bahwa transaksi mangpaindan doi merupakan hal yang dianjurkan dalam ajaran Islam. Bahkan secara umum salah satu bentuk sedekah dalam ajaran Islam yakni memberi pinjaman. Paradigma tersebut dapat menjadi determinan masyarakat untuk tetap melestarikan bentuk tanggungjawab sosial yakni mangpaindan doi.

\section{TINJAUAN TEORITIK}

\section{Utang Piutang dalam Islam}

Istilah utang piutang dalam Islam terbagi menjadi dua yakni al-qardh dan al-dayn, makna al-qardh ialah menyerahkan harta (uang) sebagai bentuk kasih sayang kepada siapa saja yang memanfaatkannya dan dia akan mengembalikannya pada sesuai dengan padanannya (Herispon, 2017), sedangkan al-dayn ialah sesuatu yang yang berada dalam tanggungjawab orang lain (Huda et al, 2012). Menurut al-Mu'jam al-Wasid kata dayn adalah utang yang bertempo sedangkan qardh utang yang tidak bertempo. Qardh sesuatu pemberian harta kepada orang lain dengan mengharapkan pengembalian darinya. Jadi, baik kata dayn maupun kata qardh adalah kata yang bermakna utang yang memiliki tempo dan tidak bertempo (Ramdansyah, 2016). 


\section{Transaksi "Mangpaindan Doi"}

Secara sederhana transaksi dipahami sebagai persetujuan antara dua orang atau lebih dalam kegiatan ekonomi. Sala satu transaksi yang telah dijelaskan sebelumnya adalah utang piutang. Utang piutang dalam masyarakat Lunjen kabupaten Enrekang menyebutnya dengan mangpaindan doi. Mangpaindan artinya meminjamkan sedangkan, doi artinya uang, jadi dapat dipahami bahwa transaksi mangpaindan doi lebih spesifik pada seseorang/ lembaga yang meminjamkan uang (kreditur) kepada sang peminjam (debitur).

Transaksi mangpaindan doi pada masyarakat Lunjen memiliki nilai kebijaksanaan sosial yakni tolong menolong (ta'awun). Pada dasarnya transaksi tersebut dilaksanakan ketika ada masyarakat yang membutuhkan uang untuk suatu pembiayaan dan meminta kepada salah satu masyarakat yang memiliki kemapaman materil. Praktik transaksi manpaindan doi memiliki makna yang sama dengan istilah Qardh dalam fiqh Islam, yakni kreditur memberikan pinjaman uang kepada debitur dan akan dikembalikan dikemudian hari uang tersebut tanpa jangka waktu dengan nominal yang sama.

Transaksi mangpaindan doi atau utang piutang pada masyarakat Lunjen menggunakan objek transaksi dengan uang (fiat money). Objek transaksi menggunakan uang akan mengalami penurunan nilai atau dikenal dengan istilah inflasi. Nilai dari berkurangnya nilai uang tersebut dapat dipahami sebagai bentuk sedekah dari kreditur ke debitur. Hal tersebut terjadi karena transaksi mangpaindan doi mengalirkan (flow) uang pinjaman untuk dipergunakan oleh debitur dan kemudian memberikan nilai tambah (value added).

\section{Uang dalam Konsep Islam}

Uang dalam ilmu ekonomi tradisional didefenisikan sebagai setiap alat tukar yang dapat diterima secara umum. Alat tukar itu dapat berupa benda apapun yang dapat diterima oleh setiap orang di masyarakat dalam proses pertukaran barang dan jasa. Sedangkan dalam ilmu ekonomi modern, uang didefinisikan sebagai sesuatu yang tersedia dan secara umum diterima sebagai alat pembayaran bagi pembeli barang atau jasa serta kekayaan berharga lainnya, dan juga untuk pembayaran utang (Jamaluddin, 2013).

Dalam kepustakaan teori moneter uang dikenal mempunyai empat fungsi, dua diantaranya merupakan fungsi yang sangat mendasar sedangkan dua lainnya adalah fungsi tambahan (Boediono, 2017). Dua fungsi dasar tersebut adalah sebagai alat tukar (means of exchange) dan sebagai alat penyimpan nilai/ daya beli (store of value), sedangkan dua fungsi tambahan yakni satuan hitung (Unit of Account) dan ukuran untuk pembayaran masa depan (standar for deferred payment). 
Pada umumnya, ada dua jenis uang yakni uang komoditas (comodity money) dan uang fiat (fiat money) (Mankiw, 2018). Uang Komoditas (Comodity money) yakni uang berbentuk komoditas dengan memiliki nilai intrinsik seperti emas. Sedangkan uang fiat (fiat money) merupakan uang yang tidak memiliki nilai intrinsik. Menurut Mishkin, uang fiat (fiat money) adalah uang kertas yang dikeluarkan oleh pemerintah sebagai alat pembayaran yang sah (pegertian sah adalah uang tersebut diterima sebagai pembayaran utang) tetapi tidak dikonversi ke dalam bentuk koin atau logam berharga (Jamaluddin, 2013).

Hukum uang kertas ditinjau dari sisi Syariah yakni ketika suatu benda ditetapkan sebagai mata uang yang sah, maka barang tersebut telah berubah fungsi dari barang biasa menjadi alat tukar dengan segala fungsi turunannya. Jumhur ulama telah sepakat bahwa illat dalam emas dan perak yang diharamkan pertukarannya kecuali serupa dengan serupa, sama dengan sama oleh Rasulullah SAW adalah karena tsumuniyyah, yaitu barang-barang tersebut menjadi alat tukar, penyimpanan nilai di mana semua barang ditimbang dan dinilai dengan nilainya. Oleh karena itu, ketika uang kertas telah menjadi alat pembanyaran yang sah, sekalipun tidak dilatarbelakangi lagi oleh emas, maka kedudukannya dalam hukum sama dengan kedudukan emas dan perak yang pada waktu Al-qur'an diturunkan tengah menjadi alat pembanyaran yang sah, karena itu riba juga berlaku pada uang kertas. Uang kertas juga diakui sebagai harta kekayaan yang harus dikeluarkan zakat dari padanya dan zakat pun sah dikeluarkan dalam bentuk uang kertas. Begitu pula ia dapat digunakan sebagai alat untuk membayar mahar (Nasution, 2006).

Secara konvensional teori keuangan dapat disederhanakan menjadi dua jenis yakni teori stock concept dan teori flow concept. Perbedaan teori sebelumnya terletak pada asumsi yang dipakai serta cara pandang dan model analisis yang diterapkan. Dalam flow concept uang dianggap sebagai public good, sedangkan paradigma stock concept melihat uang sebagai private good. Flow concept memisahkan uang dan modal, dimana uang diasumsikan selalu dalam keadaan flow (mengalir) sedangkan modal dianggap sebagai stock. Akan tetapi dalam pandangan stock concept, uang maupun modal sama-sama dianggap stock (Yahya dan Agunggunanto, 2011).

Ekonomi syariah memandang uang merupakan public good yang harus selalu dalam keadaan mengalir/ flow. Paradigma flow concept memiliki persamaan persepsi dengan teori uang menurut Al-Ghazali yakni uang sebagai media pertukaran dan benda yang dijadikan uang harus dihilangkan nilai intriksinya. Maka dapat dipahami bahwa kerangka flow concept, mata uang hanya akan berfungsi sebagai uang apabila ia beredar atau mengalir dalam masyarakat dan menghasilkan nilai tambah (value added). 


\section{Fenomena Inflasi}

Salah satu fenomena moneter yang sangat penting dan dijumpai di hampir semua negara di dunia adalah inflasi. Inflasi adalah kecendrungan dari harga-harga untuk naik secara umum dan terus-menerus. Kenaikan harga dari satu atau dua barang saja tidak di sebut inflasi, kecuali bila kenaikan tersebut meluas mengakibatkan sebagian harga barang-barang lainnya naik (Boediono, 2013).

Badan Pusat Statistik (BPS) menghitung inflasi IHK berdasarkan karakter perkembangan harga barang dan jasa (permanen/persistem dan sementara/temporer) dan berdasarkan tujuan pengeluaran. Komoditas didalam keranjang IHK dikelompokan kedalam komoditas yang pergerakan harga yang sifatnya persistem/menetap yang merupakan indikator inflasi inti (core inflation) dan komoditas yang pergerakannya temporer. Komoditas yang pergerakan temporer dapat dibedakan kedalam kelompok komoditas harganya bergejolak yakni indikator inflasi volatile foods dan kelompok komoditas yang perkembangan harganya diatur oleh pemerintah, yakni indikator inflasi administered prices (Bank Indonesia, 2018).

Sedangkan, inflasi IHK berdasarkan tujuan/alasan pengeluaran dikelompokan menjadi tujuh bagian, sebagai berikut: kelompok bahan makan, kelompok makanan jadi, minuman, dan tembakau, kelompok perumahan, air, gas, dan bahan bakar, kelompok sandang, kelompok kesehatan, kelompok pendidikan, rekreasi, dan olahraga, dan kelompok transportasi, komunikasi, dan keuangan (BPS, 2018).

Fenomena inflasi di Indonesia merupakan salah satu penyakit ekonomi makro yang meresahkan pemerintah dan terlebih bagi masyarakat. Fenomena struktural ini disebabkan oleh kesenjangan dalam perekonomian disebut structural bottlenecks. Structural bottlenecks terjadi dalam tiga hal, yakni supply pertanian yang tidak elastis, cadangan valuta asing yang terbatas akibat pendapatan ekspor lebih kecil dari pembiayaan import, dan pengeluaran pemerintah yang terbatas. Structural bottleneks inilah yang menjadikan inflasi yang berkepanjangan dan sulit diselesaikan dalam jangka waktu yang pendek. Upaya yang dapat dilakukan untuk pengendalian inflasi seperti meningkatkan supply bahan pangan, mengurangi defisit APBN, meningkatkan cadangan devisa, dan memperbaiki sekaligus meningkatkan kemampuan sisi penawaran agregat (Atmadja, 1999).

\section{Sedekah dalam Perspektif Islam}

Secara bahasa kata sedekah berasal dari bahasa Arab shodakota yang secara bahasa berarti tindakan yang benar. Pada awal pertumbuhan Islam, sedekah diartikan sebagai pemberian yang disunnahkan. Tetapi, setelah kewajiban zakat disyariatkan yang dalam Al- 
Qur'an sering disebutkan dengan kata shadaqah maka shadaqah mempunyai dua arti, yakni shadaqah sunah atau tathawwu' (Infak) dan wajib (zakat) (Ghazali et al, 2010). Sedangkan sedekah secara terminologi adalah suatu akad pemberian suatu benda oleh seseorang kepada orang lain karena mengharapkan keridhaan dan pahala dari Allah SWT dan tidak mengharapkan sesuatu imbalan jasa atau penggantian (Mardani, 2012).

Secara Ijma, ulama menetapakan bahwa hukum sedekah adalah sunah. Islam mensyariatkan sedekah karena didalamnya terdapat unsur pertolongan kepada pihak yang membutuhkan. Didalam Al-qur'an banyak ayat yang menganjurkan untuk bersedekah, diantaranya firman Allah SWT QS. Al-Baqarah/2: 280.

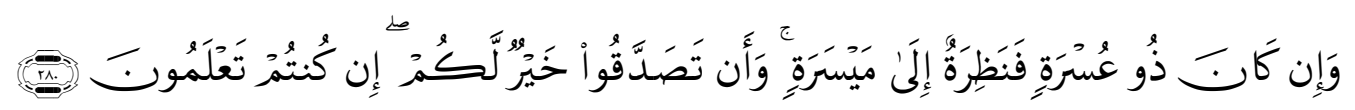

Terjemahnya:

Danjika (orang yang berhutang itu) dalam kesulitan, Maka berilah tenggang waktu sampai Dia memperoleh kelapangan. Dan jika kamu menyedekahkannya, itu lebih baik bagimu, jika kamu mengetahui.

Dari ayat sebelumnya menjelaskan transaksi utang piutang dan himbauan jika seseorang kesulitan membayar utangnya maka sebaiknya pemberi utang memberikan tenggang waktu ketika yang berutang telah mampu melunasi utang tersebut. Dan jika pemberi utang membebaskan yang berutang maka hal tersebut lebih baik. hal tersebut dipahami jika seseorang mengerti pesan-pesan moral dan kemanusiaan yang diajarkan oleh Allah SWT.

Dalam Hadits Rasulullah SAW. memerintahkan agar ummatnya bersedekah meskipun dalam jumlah yang sedikit, yang artinya:

"sedekah tidak akan mengurangi harta, Allah tidakakan menambah kepada hamba sebab suka memaafkan kecuali baginya kemuliaan, dan tidak seorang itu merendah diri kecuali Allah akan mengangkat derajatnya”. (HR. Muslim).

Sedekah dalam konsep Islam mempunyai arti yang luas, tidak hanya terbatas pada pemberian sesuatu yang sifatnya materil kepada orang miskin, tetapi lebih dari itu, sedekah mencakup perbuatan kebaikan, baik bersifat fisik maupun nonfisik seperti, membantu orang yang membutuhkan pertolongan, mendamaikan dua orang yang berselisih dengan adil, mengajari orang hingga mengerti, dan memberi pinjaman atau hutang.

\section{Shari'a Enterprise Theory}

Sharia Enterprise Theory (SET) merupakan enterprise theory yang telah diinternalisasi dengan nilai-nilai Islam guna menghasilkan teori yang transendental dan lebih humanis (Purwitasari dan Chariri, 2018). Triyuwono (2007) mengemukakan bahwa SET 
dikembangkan berdasarkan pada metafora zakat yang memiliki karakter keseimbangan. Secara umum, nilai keseimbangan yang dimaksud adalah keseimbangan antara nilai-nilai maskulin dan nilai-nilai feminin. SET menyeimbangkan nilai egoistik (maskulin) dengan nilai altruistik (feminin), nilai materi (maskulin) dengan nilai spritual (feminin), dan seterusnya. Dalam syari'ah Islam, bentuk keseimbangan tersebut secara konkrit diwujudkan dalam salah satu bentuk ibadah, yaitu zakat. Zakat (yang kemudian dimetaforakan menjadi "metafora zakat”) secara implisit mengandung nilai egoistik-altruistik, materi-spiritual, dan individujama'ah.

Pada dasarnya SET memiliki kandungan kepedulian pada segala stakeholders. SET memiliki cakupan akuntabilitas yang lebih luas dibanding dengan Entity theory (ET). Akuntabilitas yang dimaksud adalah akuntabilitas kepada tuhan, manusia, dan alam. Bentuk pertanggungjawaban yang dimaksud ialah bagaimana suatu entitas atau pribadi mendahulukan yang telah mengadakan apa yang telah di kelola dan kepada siapa dibagikan serta dari manakah sumbernya (Husain dan Abdullah, 2015).

Konsekuensi dari SET yakni Akuntansi syariah tidak lagi menggunakan konsep income dalam pengertian laba, akan tetapi menggunakan nilai tambah (value added). Menurut Triyuwono, nilai tambah dibagi menjadi tiga yakni nilai tambah ekonomi seperti uang, nilai tambah mental seperti rasa altruistik, senang, dan persaudaraan, dan terakhir nilai spritual seperti rasa ikhlas dan kehadiran tuhan. Akan tetapi nilai tambah sebelumnya belum bisa dikatakan nilai tambah syariah (Sharia value added) karena mesti diketahui nilai tambah tersebut diperoleh, diproses, dan didistribusikan secara halal (Triyuwono, 2007).

\section{METODE PENELITIAN}

Penelitian ini menggunakan paradigma penelitian kualitatif. Penelitian kualitatif merupakan suatu penelitian yang bermaksud memahami fenomena tentang apa yang dialami oleh subjek penelitian misalnya perilaku, persepsi, motivasi, tindakan, dan lain-lain secara holistik, dengan cara deskripsi dalam bentuk kata-kata dan bahasa pada suatu konteks khusus yang alamiah serta dengan memanfaatkan berbagai metode alamiah (Tohiri, 2013). Dalam penelitian ini, peneliti menggunakan pendekatan fenomenalogi agar selalu fokuskan untuk menggali, memahami, dan menafsirkan arti fenomena, peristiwa, dan hubungannya dengan orang-orang biasa dalam situasi tertentu (Yusuf, 2014). Sedangkan sumber data dalam penelitian ini data primer dimana peneliti secara langsung melakukan wawancara dan data sekunder dari publikasi Badan Pusat Statistik tentang laju inflasi.

Teknik pengumpulan data data dalam penelitian kualitatif sangat berpengaruh pada hasil penelitian nantinya oleh karena itu peneliti menggunakan teknik pengumpulan data 
yaitu wawancara dan dokumentasi. Peneliti melakukan wawancara kepada pihak kreditur, pihak debitur, tokoh agama, dan tokoh masyarakat di desa Lunjen. Segala hasil pengumpulan data akan di analisis peneliti dengan menggunakan formulasi sebagai berikut:

$$
\begin{aligned}
& \mathrm{SQ}=\mathrm{Q}-\mathrm{PV}^{1}-\mathrm{PV}^{2}-\mathrm{n} \\
& \mathrm{PV}=\frac{\mathrm{FV}}{(1+\mathrm{I})^{\mathrm{n}}} \\
& \mathrm{SQ}=\mathrm{Q}-\frac{\mathrm{FV}}{(1+\mathrm{I})^{\mathrm{n}}}
\end{aligned}
$$

Keterangan : $\mathrm{SQ}=$ Sedekah Qardh

$\mathrm{Q}=\mathrm{Q}$ ardh

$\mathrm{PV}=$ Present Value

$\mathrm{FV}=$ Future Value

I = Tingkat Inflasi

$\mathrm{n} \quad=$ Periode $q a r d h$

\section{HASIL DAN PEMBAHASAN}

\section{Al-Qardh dalam Transaksi Mangpaindan Doi}

Utang piutang dalam Islam dikenal dengan dua istilah yakni al-qardh dan al-dayn. Perbedaan mendasar dari istilah tersebut yakni perjanjian tempo pengembalian utang dan pengembalian sesuai dengan padananya, dimana al-qardh merupakan utang yang tidak bertempo sedangkan al-dayn merupakan utang bertempo. Bertempo dalam arti kesepakatan waktu pengembalian utang piutang.

Setelah melakukan wawancara dengan informan kreditur yakni ibu Rawasia, beliau mengatakan bahwa tidak ada perjanjian tentang waktu pengembalian utang karena uang yang diberikan merupakan tabungan sekolah untuk anaknya, jadi pengembalian diharapkan ketika anak ibu Rawasia mulai kulia. Hal tersebut sesuai dengan ungkapan Ibu Rawasia yang mengatakan:

"saya sampaikan kalau misalnya nanti, karena saat sekarang saya belum pakai, tapi kalau anak saya sudah mau sekolah, ada tidak ada, harus ada”

Dari ungkapan tersebut tidak ada perjanjian secara spesifik mengenai waktu pengembalian utang dari ibu Nurbaya sebagai iparnya. Akan tetapi ungkapan jika anak ibu Rawasia sudah mau kulia, maka uang tersebut harus dikembalikan. Ungkapan tersebut bukan sebagai perjanjian waktu antar dua belah pihak, tapi hanya sebagai penyampaian bahwa uang yang di pinjamkan merupakan tabungan untuk kulia anak ibu Rawasia nantinya. Secara ekonomi keluarga ibu Rawasia termasuk keluarga yang mampu berhubung suaminya merupakan perantau di Malaysia. 
Selain itu informan kreditur lainnya yakni ibu Herni yang berprofesi sebagai Guru di MIS Rumbia dan suami bekerja sebagai pedangang. Ibu Herni mengatakan tidak ada perjanjian mengenai waktu pelunasan saat melakukan Transaksi mangpaindan doi dengan saudaranya yang saat itu membutuhkan uang untuk biaya kulianya. Bahkan tidak ada pembahasan mengenai waktu pelunasan utang tersebut, hanya sekedar konteks kata ungkapan ingin meminjam uang dari saudaranya tersebut. sesuai dengan ungkapannya yang mengatakan:

"edda, tidak ada perjanjian"

Hasil penelitian yang telah dilakukan peniliti mendapatkan temuan bahwa transaksi mangpaindan doi merupakan utang piutang yang tidak bertempo. Hal tersebut sesuai dengan istilah al-qardh dalam fiqh Islam. Transaksi mangpaindan doi tidak memiliki tempo pengembalian karena pada dasarnya masyarakat yang melakukan transaksi mangpaindan doi merupakan masyarakat yang memiliki kemapanan materi dan yang diberikan pinjaman merupakan sanak keluarga yang dapat di percaya.

Utang piutang dalam Islam merupakan transaksi muamalah yang di perbolehkan. Menurut informan tokoh agama yakni ustads Safar, beliau mengatakan bahwa utang piutang diperbolehkan jika mendesak, sesuai dengan ungkapannya:

“yamo jo'o, yang pertama itu dalam agama islam kita tidak dianjurkan untuk berutang, artinya kalau tidak mendesak kita tidak dianjurkan berutang tapi kalau misalnya dalam kondisi yang dibutuhkan, berutang itu boleh, cuman berutang itu istilahnya orientasinya menolong bukan bisnis”

Ustads Safar merupakan tokoh agama yang ada di desa Lunjen. Profesi beliau sebagai guru dan menjabat sebagai kepala sekolah di dua SD sekaligus, yakni SDN no. 38 Kolai dan SD Islam terpadu Rumbo. Dari ungkapan ustads Safar sebelumnya, pada dasarnya kaum muslim tidak dianjurkan untuk berutang, akan tetapi diperbolehkan jika dalam kondisi yang mendesak. Pandangan ustads Safar mengenai transaksi mangpaindan doi hanya untuk menolong dan terlepas dari unsur bisnis.

Hal tersebut sesuai dengan sesuai dengan prinsip utang menurut Beik dalam buku keuangan publik Islam, yakni pertama harus didasari bahwa utang itu merupakan alternatif terakhir ketika segala usaha mendapatkan dana secara halal dan tunai mengalami kemandekan. Maksudnya terdapat unsur keterpaksaan untuk mendapatkan nilai dan bukan unsur kebiasaan. Kedua, jika terpaksa berutang, jangan berutang diluar kemampuan. Hal ini dalam istilah syariah disebut dengan ghalabatiq dayn atau terlilit utang. Ketiga, jika utang telah dilakukan, harus ada niat untuk membayarnya (Huda et al, 2012). 
Temuan peneliti mengenai mekanisme transaksi mangpaindan doi seperti saksi dan penulisan saat transaksi, yakni peneliti mendapatkan jawaban dari ibu Rawasia yang mengatakan bahwa saat transaksi dilakukan tidak ada saksi yang hadir dan tidak ada bentuk tertulis dari kesepakatan transaksi tersebut. Hal tersebut sesuai dengan ungkapannya:

"edda karena di kua bang sangsuranki, bukan orang lain, ya bang lan penawanko jo'o"

Dari ungkapan tersebut dapat ditarik faktor tidak adanya saksi dan bentuk tertulis saat transaksi karena adanya hubungan kekerabatan dari dua pihak, dimana ibu Nurbaya merupakan ipar ibu Rawasia. Selain itu adanya unsur kepercayaan atas dasar kekeluargaan dari ibu Rawasia sehingga tidak mesti untuk menghadirkan saksi dan penulisan transaksi.

Hal yang sama dengan transaksi mangpaindan doi ibu Herni kepada saudaranya atas nama Ammar. Transaksi mangpaindan doi yang mereka lakukan lewat komunikasi tidak secara langsung atau handphone. Perjanjian transaksi tersebut terjadi ketika Ammar menelpon ibu Herni untuk dipinjamkan uang untuk biaya kulianya. Dari komunikasi tersebut terjadi persetujuan ibu Herni untuk mengirimkan unag pinjaman ke Ammar lewat transfer ATM. Saat terjadinya komunikasi lewat telpon dan transfer tidak ada saksi dan penulisan kesepakatan transaksi, hanya struk yang keluan dari mesin ATM setelah ibu Herni mengirim uang.

Mekanisme transaksi mangpaindan doi pada umunya tidak memiliki saksi saat transaksi, tidak ada bentuk tertulis, dan perjanjian pengembalian tidak bertempo. Pandangan ustads Safar mengenai transaksi mangpaindan doi yang dilakukan masyarakat Lunjen sangat menarik. Ustads Safar mengatakan bahwa masyarakat Lunjen memberikan utang piutang sangat di pengaruhi oleh budaya dan juga faktor ketidakpahaman masyarakat Lunjen mengenai mekanisme transaksi, seperti ungkapannya:

"jadi sebenarnya, utang piutang didaerah kita itu sangat di pengaruhi oleh budaya, ketika ada keluarga yang meminjam, sangat na anggap ia naif to tau ke dicatai, merasa kumua edda dipercayai karena orang yang memberi pinjaman atau pinjam meminjam di dearah kita untuk diwariskan turun temurun, istilahnya memang didasarkan pada kepercayaan, sehingga mereka tidak merasa perluh menulisnya, kedua mereka tidak paham misalnya memang utang piutang harus ada saksi dan atau tidak ada saksi harus dicatat, tapikan tidak, mereka meminjamkan atas dasar kekeluargaan, sehingga itu yang turun temurun, bahkan orang di daerah kita itu menagih saja utang itu orang malu, mereka memang memberi pinjaman atas dasar kekeluargaan"

Dari ungkapan tersebut, peniliti mendapatkan informasi bahwa transaksi mangpaindan doi yang dilakukan msyarakat Lunjen sangat dipengaruhi oleh budaya, dimana praktik utang piutang tidak memiliki saksi dan bentuk tertulis. Selain itu, transaksi mangpaindan doi terdapat unsur kepercayaan atas dasar kekeluargaan sehingga tidak perluh 
untuk membuat penulisan transaksi. Dan juga tindakan menangih utang merupakan sesuatu hal yang hindari oleh masyarakat Lunjen.

Menurut peneliti, faktor utama tidak adanya saksi, penulisan transaksi, dan tempo pengembalian utang karena transaksi mangpaindan doi memiliki unsur kepercayaan atas dasar kekeluargaan. Hal tersebut membuat masyarakat tidak harus mimiliki saksi dan penulisan saat transaksi. Selain itu, faktor lainnya yakni ketidakpahaman masyarakat tentang aturan utang piutang yang seharusnya memiliki saksi dan menuliskannya.

\section{Nilai Ta'awun dari Transaksi Mangpaindan Doi}

Utang piutang dalam konsep Islam merupakan transaksi yang mengandung nilai ta'awun (tolong menolong). Utang piutang disebut sebagai ibadah sosial karena memiliki nilai terutama guna membantu antar sesama yang tidak mampu secara ekonomi atau sedang membutuhkan. Transaksi utang piutang pada dasarnya terlepas dari unsur komersial dan usaha yang berorientasi pada keuntungan (Ramdansyah, 2016).

Menurut bapak Muh. Solihin Dawaru selaku informan tokoh masyarakat dan menjabat sebagai kepala Dusun Galung desa Lunjen tahun periode 2018-2023, mengatakan bahwa transaksi mangpaindan doi sangat penting dalam masyarakat karena dapat sebagai instrumen tolong menolong antar masyarakat yang memiliki kemapanan materi dan masyarakat yang membutuhkan bantuan uang secara mendadak. Hal tersebut sesuai dengan ungkapan dari Bapak Solihin yang mengatakan:

"anna tang parallu jio pangindan doi, orang yang menolong tanpa mengharap imbalan, niat ikhlas karena Allah, sudah jelas amal yang baik”

Ungkapan tersebut menandakan bahwa transaksi mangpaindan doi memiliki nilai ta'awun (tolong menolong). Hal tersebut dikarenakan dalam transaksi mangpaindan doi tidak memiliki imbalan seperti tambahan pengembalian atau terlepas dari unsur bisnis/ komersial.

Hasil wawancara peniliti dengan informan kreditur dan debitur tentang alasan transaksi mangpaindan doi, peneliti temukan alasan yang beragam masyarakat Lunjen seperti, biaya kulia, ongkos uang masuk perguruan tinggi, ongkos perjalanan merantau dan biaya untuk wisuda. Berbagai alasan sebelumnya mengindikasi bahwa transaksi mangpaindan doi terlepas dari unsur bisnis. Seperti hasil wawancara dengan ibu Rawasia selaku kreditur, yang mengatakan:

"minta tolong kalau bisa, karena anaknya mau masuk perguruan tinggi dan harus membayar uang masuk, dan uangnya tidak cukup" 
Hal tersebut menjadi alasan ibu Rawasia untuk memberikan peminjaman uang kepada iparnya bernama Ibu Nurbaya, karena anak ibu Nurbaya harus membayar uang masuk perguruan tinggi. Pada saat itu uang ibu Nurbaya tidak cukup untuk membayar uang masuk anaknya yang masuk perguruan tinggi. Upaya yang dilakukan yakni berkunjung ke rumah ibu Rawasia untuk meminta bantuan untuk dipinjamkan. Berhubung karena kedua pihak merupakan kerabat maka ibu Rawasia memberikan pinjaman.

Berbeda dengan informan kreditur ibu Herni melakukan transaksi mangpaindan doi karena saudara beliau membutuhkan uang mendadak untuk pembayaran kulia. Perjanjian ibu Herni dengan Ammar tidak secara langsung atau melalui telpon. Alasan ibu Herni memberikan pinjaman karena pada saat itu masih memiliki tabungan dan yang meminta pinjaman merupakan saudaranya.

Selain itu, peneliti juga mewawancarai informan debitur atas nama bapak Jamuddin. Bapak Jamuddin menjelaskan alasan beliau melakukan peminjaman di Dana Abadi karena istrinya membutuhkan ongkos wisuda di sala satu perguruan tinggi. Pada saat itu kondisi keuangan keluarganya tidak cukup untuk digunakan membayar biaya wisuda. Sesuai dengan ungkapannya:

"la mang anui tanta, la wisudai"

Tindakan bapak Jamuddin untuk melakukan peminjaman di Dana Abadi karena sangat mudah dan terlepas dari unsur bisnis. Dana Abadi merupakan dana hibah untuk dipergunakan kepada masyarakat Lunjen khususnya Madata dalam keperluan yang mendadak seperti biaya rumah sakit, hal tersebut sesuai dengan ungkapan bapak Jamuddin yang mangatakan:

"na kua Haji, edda na papolei jio doi, eddamo na la alai, yara jo’o bantuki to parallu, to masaki tiba-tiba, na male jio rumah sakit tapa na indanmi, untuk keperluan mendadak, susi tu lako"

Ungkapan tersebut menerangkan bahwa Dana Abadi merupakan kumpulan dana dari keluarga Manggara Mappole yang di titipkan kepada iman mesjid Nurul Imam Madata untuk dikelola dan di salurkan kepada masyarakat yang membutuhkan dana secara mendadak dan untuk modal usaha bagi masyarkat dalam bertani. Dana Abadi dikategorikan sebagai Hibah karena uang yang diberikan ke Imam mesjid tidak akan di ambil kembali oleh keluarga Manggarra.

Dari hasil informasi sebelumnya, peneliti temukan alasan masyarakat melakukan transaksi utang piutang dikarenakan kebutuhan yang mendadak, seperti pembayaran uang masuk perguruan tinggi, pembayaran uang kulia, dan biaya untuk wisuda. Beberapa alasan sebelumnya menandakan bahwa transaksi mangpaindan doi memiliki nilai ta'awun (tolong 
menolong). Nilai ta'awun terlihat dari kesediaan masyarakat meminjamkan uangnnya tanpa pamrih.

Selain faktor alasan peminjaman, nilai ta'awun dari transaksi mangpaindan doi yakni orientasi peminjaman semata karena menolong dan terlepas dari unsur bisnis. Hasil wawancara dengan ibu Rawasia, ibu Herni, dan bapak Jamuddin mereka mengatakan bahwa nominal transaksi yang di kembalikan sesuai dengan nominal yang dipinjamkan, artinya tidak ada penambahan atau pengurangan dari transaksi mangpaindan doi.

Pandangan ustasd Safar selaku informan tokoh agama berargumen bahwa utang piutang memiliki orientasi menolong bukan bisnis. Artinya setiap masyarakat yang memberikan pinjaman karena melihat kondisi atau latar belakang yang meminjam. Latar belakang yang dimaksud seperti kondisi ekonomi, alasan meminjam, dan unsur kepercayaan yang mendorong transaksi mangpaindan doi dilakukan.

\section{Uang sebagai Objek Transaksi Mangpaindan Doi}

Pada aspek proses transaksi peminjaman, peneliti akan dapat menemukan objek transaksi mangpaindan doi. Peneliti berasumsi bahwa objek transaksi akan terlihat dari proses peminjaman yang dilakukan oleh kreditur dan debitur. Oleh karen itu pada pembahasan ini, peneliti akan menjelasakan proses transaksi yang dilakukan oleh informan kreditur dan debitur. Pertama dari informan kreditur ibu Rawasia yang memberikan pinjaman secara langsung di rumahnya kepada iparnya ibu Nurbaya senilai Rp 5.000.000,oo. Selain itu informan ibu Herni mengatakan:

"melalui telpon, kemudian saya transfer"

Sedangkan proses transaksi mangpaindan doi ibu Herni melalui transfer di Bank dengan nominal Rp. 3.000.000,oo kepada saudaranya atas nama Ammar. Proses transaksi mangpaindan doi yang dilakukan ibu Herni sebelumnya melalui transfer karena saudaranya atas nama Ammar menelpon untuk dipinjamkan uang. Artinya semua transaksi peminjaman menggunakan uang Rupiah (Rp). Sedangkan bapak Jamuddin sebagai debitur, diberikan pinjaman dengan nominal Rp. 3.000.000,oo dari Dana Abadi.

Penggunaan uang Rupiah sebagai objek transaksi mangpaindan doi karena uang merupakan alat transaksi yang sah dan dapat diterima secara umum. Faktor lainnya yakni sumber objek transaksi mangpaindan doi ialah dari tabungan kreditur, otomatis tabungan tersebut dalam bentuk uang di bank. Selain itu objek peminjaman digunakan debitur untuk keperluan yang harus menggunakan uang seperti pembayaran uang masuk kulia dan pembayaran biaya wisuda. 


\section{Pengurangan Nilai Uang dari Transaksi Mangpaindan Doi}

Hasil pemaparan penelitian sebelumnya membuktikan bahwa objek transaksi mangpaindan doi yakni menggunakan uang (fiat money), dimana uang selalu mengalami pengurangan nilai atau inflasi. Fenomena tersebut menjadi masalah pada transaksi utang piutang. Dari beberapa masyarakat Lunjen yang menjadi informan, peneliti temukan kurangnya pamahaman masyarakat tentang fenomena inflasi akan tetapi mereka merasakan dampak dari pengurangan nilai uang setiap tahunnya.

Pengembalian utang pada transaksi mangpaindan doi sesuai dengan nilai nominal saat transaksi peminjaman. Artinya tidak ada penambahan maupun pengurangan saat pengembalian utang. Wacana tindakan indeksasi sebagai bentuk keadilan dalam pengembalian utang piutang dapat menimbulkan perbuatan riba, sesuai dengan pemikiran Syafi'i Antonio yang menuliskan:

"inflasi tidak bisa dijadikan alasan atas pengambilan bunga uang walaupun sebagai konpensasi terhadap penurunan daya beli uang dengan alasan inflasi tidak dapat dijadikan sebagai illat dalam hukum, dan juga dijelaskan bahwa pada zaman Rasulullah saw telah terjadi inflasi, namun Rasulullah saw tidak pernah membenarkan pengambilan bunga pinjaman atas dasar faktor ini”

Solusi dari masalah transaksi mangpaindan doi menurut ustads Safar, beliau menerangkan solusi untuk menghindari perbuatan riba saat transaksi utang piutang yakni tidak adanya perjanjian masalah penambahan saat pengembalian utang. Jika penambahan terjadi saat pengembalian tanpa ada perjanjian sebelumnya dan niat ikhlas memberi tambahan pelunasan utang, maka hal tersebut diperbolehkan. Sesuai dengan ungkapannya yang mengatakan:

"solusi untuk menghindar riba atau nilai inflasi diperhitungkan, istilahnya canning atih, misalnya saya pinjam satu jutah kemudian dua tahun saya bayar, tidak ada perjanjian ada bunga dan seterusnya, karena nilainya sudah berkurang, jadi kupalabï tapi itu iklas dan tidak ada pembicaraan”

Hal tersebut sesuai dengan referensi buku fiqh ekonomi syariah yang menerangkan Apabila terjadi kelebihan pembayaran dari jumlah uang pokok atau sejumlah yang diterimah oleh orang yang berutang, maka dapat dibedakan menjadi dua macam yaitu kelebihan yang tidak diperjanjikan, apabila kelebihan pembayaran yang dilakukan oleh orang yang berutang bukan didasari karena perjanjian sebelumnya, maka kelebihan itu diperbolehkan (halal) bagi orang yang berpiutang, dan merupakan kebaikan bagi yang berutang, dan kelebihan yang diperjanjikan, kelebihan pembayaran oleh orang yang berutang yang didasarkan oleh perjanjian hukumnya dilarang (haram) (Mardani, 2012).

Secara teknis, selanjutnya akan dijelaskan mengenai terjadinya pengurangan nilai uang pada transaksi mangpaindan doi yang terjadi pada informan masyarakat Lunjen. 
Pertama transaksi mangpaindan doi yang dilakukan oleh ibu Rawasia kepada iparnya bernama ibu Nurbaya senilai Rp 5.000.00o,oo pada tahun 2013 dan dikembalikan oleh ibu Nurbaya pada tahun 2016 setelah menjual ternak sapinya, hal tersebut sesuai dengan ungkapan ibu Rawasia:

\section{"yato mangkai baluk saping"}

Pelunasan utang ibu Nurbaya kepada ibu Rawasia setelah menjual ternak sapinya. Hasil dari penjual tersebut digunakan sebagian untuk melunasi utang ke ibu Rawasia senilai Rp. 5.000.000,o0 selama tiga tahun. Pelunasan tersebut pada dasarnya terjadi karena debitur telah mampu melunasi utangnya, tanpa ada penangihan yang dilakukan ibu Rawasia.

Kedua yakni ibu Herni memberikan pinjaman kepada Ammar selaku saudaranya senilai Rp 3.000.000,00 pada bulan Juli tahun 2017 dan dikembalikan oleh Ammar pada bulan Juli tahun 2018, tepat setahun kemudian. Sedangkan, Bapak Jamuddin selaku debitur mendapatkan pinjaman dari Dana Abadi senilai Rp 3.000.ooo,oo pada tahun 2013 dan dikembalikan pada tahun 2018, meski jatuh tempo Dana Abadi setiap enam bulan akan tetapi uang tersebut digunakan bapak Jamuddin sampai tahun 2018, artinya penetapan jatuh tempoh hanya untuk kelancaran pencatatan oleh pengelolanya. Untuk lebih jelas, peneliti akan menyajikan hasil wawancara terhadap informan kreditur dan debitur pada tabel 1.

Tabel 1. Hasil Wawancara Informan Kreditur dan Debitur

\begin{tabular}{ccccccc}
\hline No & Kreditur & Debitur & $\begin{array}{c}\text { Nominal } \\
\text { Transaksi }\end{array}$ & $\begin{array}{c}\text { Tahun } \\
\text { Peminjaman }\end{array}$ & $\begin{array}{c}\text { Tahun } \\
\text { Pembayaran }\end{array}$ & Ket \\
\hline 1 & Ibu Rawasia & Ibu Nurbaya & 5 Juta & 2013 & 2016 & Lunas \\
\hline 2 & Ibu Herni & $\begin{array}{c}\text { Bapak } \\
\text { Ammar }\end{array}$ & 3 Juta & 2017 & 2018 & Lunas \\
\hline 3 & Dana Abadi & $\begin{array}{c}\text { Bapak } \\
\text { Jamuddin }\end{array}$ & 3 Juta & 2013 & 2018 & Lunas \\
\hline
\end{tabular}

Sumber: Data Primer, diolah 2018

Dari hasil wawancara tersebut, maka dapat diketahui nominal dan jenjang waktu antara peminjaman dan pembayaran transaksi mangpaindan doi yang dilakukan oleh informan. Selanjutnya dibutuhkan data mengenai laju inflasi dari Badan Pusat Statistik (BPS) untuk menjadi acuan dalam perhitungan inflasi uang. Untuk itu peneliti akan menyajikan data laju inflasi di Indonesia tahun 2011-2018, pada tabel 2. 
Mengungkap Aspek Sedekah dalam Transaksi Mangpaindan Doi

Pada Masyarakat Lunjen Enrekang

Andi Suwandi Putra Suaib, Wahyuddin Abdullah, Muslimin Kara

DOI : $\operatorname{xxxxxxx}$

Tabel 2. Tingkat Inflasi Indonesia tahun 2011-2018

\begin{tabular}{ccc}
\hline No & Tahun & Tingkat Inflasi \\
\hline $\mathbf{1}$ & 2011 & 3.79 \\
\hline $\mathbf{2}$ & 2012 & 4.3 \\
\hline $\mathbf{3}$ & 2013 & 8.38 \\
\hline $\mathbf{4}$ & 2014 & 8.36 \\
\hline $\mathbf{5}$ & 2015 & 3.35 \\
\hline $\mathbf{6}$ & 2016 & 3.02 \\
\hline $\mathbf{8}$ & 2017 & 3.61 \\
\hline $\mathbf{8}$ & 2018 (Juli) & 2.18 \\
\hline
\end{tabular}

Sumber: BPS Data Diolah, tahun 2018

Sajian laju inflasi sebelumnya menjadi acuan peneliti untuk menentukan inflasi uang pada transaksi mangpaindan doi yang dilakukan informan kreditur dan debitur, sebagai berikut:

\section{Kreditur/ muqridl}

Ibu Rawasia, memberikan pinjaman dengan nominal 5 juta kepada ibu Nurbaya pada tahun 2013, dan ibu Nurbaya membayarnya pada tahun 2016. Jadi selama tiga tahun uang tersebut berada pada ibu Nurbaya, dengan laju inflasi pada tahun 2014 sebesar 8,36\%, tahun 2015 sebesar 3,35\%, dan tahun 2016 sebesar 3,02\%.

Ibu Herni, memberikan pinjaman dengan nominal 3 juta kepada Ammar pada bulan Juni 2017, dan Ammar membayarnya pada bulan Juni 2018. Jadi selama satu tahun uang tersebut berada pada bapak Ammar, dengan tingkat inflasi Juni 2017 - Juni 2018 sebesar $3,09 \%$.

\section{Debitur/ muqtaridl}

Bapak Jamuddin mendapatkan pinjaman dari Dana Abadi dengan nominal 3 juta pada tahun 2013, sedangkan pelunasan dilakukan pada tahun 2018. Jadi selama lima tahun uang tersebut berada pada bapak Jamuddin, dengan laju inflasi tahun 2014 sebesar 8,36\%, tahun 2015 sebesar 3,35\%, tahun 2016 sebesar 3,02\%, tahun 2017 sebesar 3,61\%, dan tahun 2018 sebesar $2,18 \%$.

Pengurangan nilai uang (inflasi) merupakan fenomena moneter yang disebabkan oleh penggunanaan jenis uang fiat (fiat money). Fiat money adalah penggunaan uang berbasis kertas yang di terbitkan oleh institusi moneter di suatu negara tanpa disokong logam mulia. Pada sistem ini uang terus diciptakan sehingga tumbuh secara eksponensial. Kondisi ini mengakibatkan ketidakseimbangan antar sektor riil dan moneter, yang mengakibatkan inflasi (Nusyamsiah, 2018). 


\section{Aspek Sedekah Transaksi Mangpaindan Doi}

Pada penjelasan di tinjauan teoritis menyebutkan bahwa sedekah dalam transaksi mangpaindan doi terdapat pada pengurangan nilai uang atau inflasi saat pengembalian. Sedekah tersebut terdapat dalam transaksi mangpaindan doi yang memiliki nilai ta'awun, objek transaksi menggunakan uang (fiat money), dan merupakan al-qardh. Menurut ustads Safar, aspek sedekah transaksi mangpaindan doi masih belum menjadi perhatian karena tidak ada tolak ukurnya, sesuai dengan ungkapannya:

"kalau mangpaindan doi itu termasuk tolong menolong, tapi bagian dari pengurangan nilai itu sepertinya belum terasa betul, eddapa na anggai to tau kua bersedekah karena tidak ada ukuran"

Maka dari itu peneliti memberikan formulasi sedekah pada penelitian ini. Formulasi sedekah merupakan rumus yang di buat oleh peneliti untuk dapat menghitung nilai sedekah al-qardh transaksi mangpaindan doi. Perhitungan tersebut diupayakan dapat menjadi acuan untuk menilai nominal sedekah pada transaksi mangpaindan doi akibat terjadinya inflasi uang. Formulasi akan digunakan peneliti untuk menghitung nominal sedekah dari informan kreditur dan debitur, sebagai berikut:

1. Kreditur

a. Ibu Rawasia

$$
\begin{aligned}
& \mathbf{S Q}=\mathbf{Q}-\underline{\mathbf{F V}} \\
& \mathbf{( \mathbf { 1 } + \mathbf { I } ^ { \mathbf { r } } ) ^ { \mathbf { n } }} \\
& \mathbf{S Q}=5.000 .000-\frac{5.000 .000}{(1+\mathbf{8 , 3 6 \%})^{1}} \\
& \mathbf{S Q}=5.000 .000-5.000 .000 \\
& \mathbf{( 1 , 0 8 3 6 ) ^ { 1 }} \\
& \mathbf{S Q}=5.000 .000-\frac{4.614 .248,8003}{(1+\mathbf{3}, \mathbf{3 5 \%})^{1}} \\
& \mathbf{S Q}=5.000 .000-\frac{4.614 .248,8003}{(1,0335)^{1}} \\
& \mathbf{S Q}=5.000 .000-\frac{4.464 .681,9548}{(1+\mathbf{3}, \mathbf{0 2} \%)^{1}} \\
& \mathbf{S Q}=5.000 .000-\frac{4.464 .681,9548}{(1,0302)^{1}} \\
& \mathbf{S Q}=5.000 .000-4.333 .801,1598 \\
& \mathbf{S Q}=\mathbf{6 6 6 . 1 9 8 , 8 4 0 2}
\end{aligned}
$$

Transaksi mangpaindan doi yang dilakukan ibu Rawasia kepada ibu Nurbaya dengan nominal Rp. 5.000.0oo,oo pada tahun 2013 dan dikembalikan sesuai padanannya pada tahun 2016. Selama tiga tahun uang tersebut berada di tangan ibu Nurbaya dimana pada tahun 2014 tingkat inflasi sebesar 8,36\%, tahun 2015 tingkat inflasi sebesar 3,35\%, dan tahun 2016 tingkat 
inflasi sebesar 3,02\%. Perhitungan sebelumnya memberikan jawaban sedekah qardh ibu Rawasia kepada ibu Nurbaya sekitar Rp. 666.198, oo.

b. Ibu Herni

$$
\begin{gathered}
\mathbf{S Q}=\mathbf{Q}-\underline{\mathbf{F V}} \mathbf{( \mathbf { 1 } + \mathbf { I } ) ^ { \mathbf { n } }} \\
\mathbf{S Q}=3.000 .000-3.000 .000 \\
\mathbf{S Q}=3.000 .000-\frac{3.000 .000}{(1+3,0309)^{1}} \\
\mathbf{S Q}=3.000 .000-\frac{3.000 .000}{1,0309} \\
\mathbf{S Q}=3.000 .000-2.910 .078,5721 \\
\mathbf{S Q}=\mathbf{8 9 . 9 2 1 , 4 2 7 9}
\end{gathered}
$$

Transaksi "mangpaindan doi" yang dilakukan ibu Herni kepada Ammar dengan nominal Rp. 3.000.000,00 pada bulan juli tahun 2017 dan dikembalikan sesuai padanannya pada bulan juli tahun 2018. Selama satu tahun uang tersebut berada di tangan Ammar dengan rata-rata inflasi yakni 3.09\%. Perhitungan sebelumnya memberikan jawaban sedekah qardh ibu Herni kepada Ammar sekitar Rp. 89.921,00.

2. Debitur

$$
\begin{aligned}
& \mathbf{S Q}=\mathbf{Q}-\underline{\mathbf{F V}} \\
& (1+I)^{n} \\
& \mathbf{S Q}=3.000 .000-3.000 .000 \\
& (1+8,36 \%)^{1} \\
& \text { SQ }=3.000 .000-3.000 .000 \\
& (1,0836)^{1} \\
& \text { SQ }=3.000 .000-\underline{2.768 .549,2802} \\
& (1+3,35 \%)^{1} \\
& \mathbf{S Q}=3.000 .000-\underline{2.768 .549,2802} \\
& (1,0335)^{1} \\
& \mathbf{S Q}=3.000 .000-\underline{2.678 .809,1729} \\
& (1+3,02 \%)^{1} \\
& \text { SQ }=3.000 .000-\underline{2.678 .809,1729} \\
& (1,0302)^{1} \\
& \text { SQ }=3.000 .000-\underline{2.600 .280,6959} \\
& (1+3,61 \%)^{1} \\
& \mathbf{S Q}=3.000 .000-\underline{2.600 .280,6959} \\
& (1,0361)^{1} \\
& \mathbf{S Q}=3.000 .000-\underline{2.509 .681,2044} \\
& (1+2,18 \%)^{1} \\
& \mathbf{S Q}=3.000 .000-\underline{2.509 .681,2044} \\
& (1,0218)^{1} \\
& \mathbf{S Q}=3.000 .000-2.456 .137,4089 \\
& \mathrm{SQ}=\mathbf{5 4 3 . 8 6 2 , 5 9 1 1}
\end{aligned}
$$


Transaksi mangpaindan doi yang dilakukan bapak Jamuddin dari Dana Abadi dengan nominal Rp. 3.000.000,00 pada tahun 2013 dan bapak Jamuddin dikembalikan sesuai padanannya pada tahun 2018. Selama lima tahun uang tersebut berada di tangan bapak Jamuddin, dimana pada tahun 2014 tingkat inflasi sebesar 8,36\%, tahun 2015 tingkat inflasi sebesar 3,35\%, tahun 2016 tingkat inflasi sebesar 3,02, tahun 2017 tingkat inflasi sebesar 3,61\%, dan tahun 2018 tingkat inflasi sebesar 2,81\%. Perhitungan sebelumnya memberikan jawaban sedekah qardh yang diperoleh bapak Jamuddin dari Dana abadi kepada senilai Rp. 543.862,o0. Nilai sedekah qardh pada dasarnya yang sebagai penanda bahwa transaksi mangpaindan doi terdapat pengurangan nilai secara otomatis karena objek transaksi menggunakan uang (fiat money).

\section{Nilai Tambah Syariah Transaksi Mangpaindan Doi}

Shariah enterprise theory (SET) merupakan teori yang dibangun dengan dasar metaforah amanah dan metaforah zakat, dengan menghendaki keseimbangan antara sifat egoistik dan altruistik. SET memiliki akuntabilitas yang luas mencakup akuntabilitas dengan Tuhan, Manusia, dan Alam. Konsekuensi dari itu yakni pengakuan income dari nilai tambah (value added) bukan lagi income dalam pengertian laba (profit) (Triyuwono, 2007).

Nilai tambah syariah (shari’ah value added) yang terdiri dari tiga bagian yakni nilai tambah ekonomi, mental, dan spritual. Pada aspek nilai tambah ekonomi, transaksi mangpaindan doi tidak memiliki keuntungan berupa materi, bahkan secara nominal transaksi setiap muqridl mengalami pengurangan nilai saat pengembalian oleh muqtaridl. Akan tetapi perluh dipahami bahwa transaksi mangpaindan doi merupakan al-qardh, memiliki nilai ta'awun, dan unsur kepercayaan atas dasar kekeluargaan. Hal tersebut menjadikan transaksi mangpaindan doi memiliki nilai ekonomi berbentuk sedekah. Nilai ekonomi berbentuk sedekah yang dimaksud yakni hasil perhitungan menggunakan formulasi yang membuktikan bahwa terdapat pengurangan nilai uang meski nominal yang sama saat transaksi pengembalian utang.

Pada aspek nilai mental, transaksi mangpaindan doi bentuk nilai tambah seperti rasa altruistik dan persaudaraan. Rasa altruistik seperti argumen dari ibu Rawasia yang mengatakan bahwa pengurangan nilai (inflasi) bukan hal yang penting, tetapi latar belakang yang akan di berikan pinjaman. Latar belakang yang dimaksud yakni kepribadian calon debitur. Hal tersebut sesuai dengan ungkapannya:

"saya tidak berpikir masalah inflasi, yang saya pikirkan latar belakang yang meminjam karena tidak semua orang dapat dipercaya” 
Sedangkan rasa persaudaraan terlihat dari mekanisme transaksi mangpaindan doi yang tidak memiliki saksi dan tidak ada penulisan bukti transaksi, hal tersebut karena transaksi mangpaindan doi memiliki unsur kepercayaan atas dasar kekeluargaan. Menurut bapak Solihin sampai sekarang belum ada kasus utang piutang di desa Lunjen yang dibawah keranah hukum, sesuai dengan argumennya yang mengatakan:

"eddapa kusading mane, berkasus sibawa-bawa lako"

Ungkapan dari bapak Solihin menandakan belum adanya kasus utang piutang di desa Lunjen yang di bawah ke ranah hukum. Hal demikian sesuai dengan penjelasan ustads Safar yang mengatakan bahwa masyarakat memiliki rasa malu untuk menangih utang. Sehingga dapat dipahami bahwa penangih utang termasuk hal yang hindari masyarakat Lunjen, apalagi membawah kasus utang ke ranah hukum.

Pada aspek nilai tambah spritual, transaksi mangpaindan doi memiliki bentuk rasa ikhlas dan kehadiran Tuhan. Sesuai dengan ungkpan dari ibu Rawasia yang mengatakan:

"kan kalau kita melonggarkan kesulitan orang lain, insyaAllah Allah juga membalas akan melonggarkan kesulitan kita, ya toda lang anungku, artinya doi jio bang kale la diapa tori toh"

Ungkapan sebelumnya memiliki aspek spritual yang tampak pada keikhlasan ibu Rawasia memberikan pinjaman. Keikhlasan tersebut didukung oleh rasa persaudaraan yang kuat. Akan tetapi yang perluh dipahami bahwa keikhlasan dan rasa persaudaraan ibu Rawasia berasal dari ketauhidannya kepada Allah. Ibu Rawasia yakin jika ada orang yang melonggarkan kesulitan orang lain maka Allah akan melonggarkan kesulitannya.

Dari penjelasan sebelumnya maka dapat di tarik kesimpulan bahwa pada transaksi mangpaindan doi memiliki nilai tambah syariah (shari’ah value added) seperti nilai tambah ekonomi pada aspek sedekah dari pengurangan nilai (inflasi), nilai tambah mental pada rasa altruistik dan juga nilai tambah spritual yakni rasa ikhlas dan rasa kehadiran Tuhan.

\section{KESIMPULAN}

Transaksi mangpaindan doi memiliki persamaan dengan istilah qardh dalam fiqh Islam. Persamaan tersebut karena transaksi mangpaindan doi dan qardh tidak memiliki tempo dan nominal yang sama saat pengembalian utang piutang. Praktik tersebut dipengaruhi oleh faktor kreditur yang memiliki kemapanan materi dan debitur merupakan sanak keluarga yang dapat dipercaya.

Pada umumnya transaksi mangpaindan doi di landasi nilai ta'awun (tolong menolong) antar masyarakat. Nilai ta'awun terlihat dari alasan muqridl melakukan transaksi 
mangpaindan doi yakni kebutuhan yang mendadak dan juga orientasi terlepas dari unsur bisnis. Selain itu, terdapat aspek sedekah dalam transaksi mangpaindan doi. Aspek sedekah tersebut akibat adanya pengurangan nilai uang atau inflasi saat proses pengembalian. Beberapa kesimpulan dari hasil penelitian, sebagai berikut:

Pertama, mekanisme transaksi mangpaindan doi yang dilakukan masyarakat Lunjen tidak memiliki saksi, tidak ada bentuk tertulis, dan tidak ada perjanjian tempo pengembalian. Hal tersebut dipengaruhi oleh faktor nilai ta'awun dan unsur kepercayaan atas dasar kekeluargaan. Kedua, inflasi uang pada transaksi mangpaindan doi terjadi antara jenjang waktu peminjaman dan pembayaran utang tersebut. Data primer berupa nominal transaksi dan jenjang waktu diperoleh dari hasil wawancara, sedangkan data sekunder berupa tingkat inflasi diperoleh dari BPS, sehingga dapat diketahui inflasi uang yang terjadi pada transaksi mangpaindan doi. Pengurangan nilai (inflasi) tersebut dipengaruhi oleh jenis uang fiat (fiat money) yang digunakan dalam transaksi. Dan ketiga, formulasi sedekah menjadi acuan untuk menghitung nominal sedekah dalam transaksi "mangpaindan doi". Hasil perhitungan sedekah qardh yang diperoleh menyatakan bahwa setiap muqridl memberikan sedekah qardh dan juga muqtaridl memperoleh sebaliknya. Transaksi mangpaindan doi memiliki nilai tambah syariah (shari'ah value added) seperti nilai tambah ekonomi pada aspek sedekah dari pengurangan nilai (inflasi), nilai tambah mental pada rasa altruistik dan juga nilai tambah spritual yakni rasa ikhlas dan rasa kehadiran Tuhan.

\section{DAFTAR PUSTAKA}

Al-Albani, M. Nashiruddin. 2007. Shahih al-Targhib wa al-Tarhib Jilid 2. Jakarta: Pustaka Sahifa.

Antonio, Syafi'I. 2001. Bank Syariah. Jakarta: Gema Insani Press.

Atmadja, Adwin S. 1999. "Inflasi Di Indonesia: Sumber-Sumber Penyebab Dan Pengendaliannya". Jurnal Akuntansi dan Keuangan. Vol. 1 No. 1.

Badan Pusat Statistik, "Inflasi: Metodologi", official website Badan Pusat Statistik, https://www.bps.go.id/subject/3/inflasi.html\#subjekViewTab2 diakses pada tanggal 9 Juli 2018.

Bank Indonesia, "Metode Perhitungan Inflasi terbaru oleh Badan Pusat Statistik", official website Bank Indonesia, https://www.bi.go.id/id/ruang-media/siaranpers/Pages/sp\%208606.aspx diakses pada tanggal 9 Juli 2018.

Boediono. 2017. Ekonomi Moneter Ed. 3. Yogyakarta: BPFE.

Departemen Agama Republik Indonesia. 2006. Al-qur'an dan Terjemahannya. Jakarta: Maghfirah Pustaka

Ghazali, Abdul Rahman, dkk. 2010. Fiqh Muamalat. Jakarta: Prenamedia Group.

Herispon, 2017. "Utang Konsumtif Rumah Tangga dalam Perspektif Konvensional dan Syariah”. Maqdis: Jurnal Kajian Ekonomi Islam. Vol. 2 No. 2.

Huda, Nurul, dkk. 2012. Keuangan Publik Islami: Pendekatan Teoritis dan Sejarah. Jakarta: Kencana. 
Husain, Saddan, dan Wahyuddin Abdullah. 2015. “Metafora Amanah Pengelolaan Dana Pihak Ketiga (DPK) Sebagai Penopang Asset Perbankan Syariah Ditinjau Dari Aspek Trilogi Akuntabilitas (Studi Kasus Pada PT. Bank BNI Syariah Cabang Makassar)”.Jurnal Iqtisaduna. Vol. 1 No. 2.

Jamaluddin. 2013. "Fiat Money: Masalah dan Solusi". Jurnal Akuntansi Multiparadigma. Vol. 4 No. 2.

Kementrian Keuangan. APBN 2018, Asumsi Dasar Ekonomi Makro, https://www.kemenkeu.go.id/apbn2018 diakses pada tanggal 26 Juni 2018.

Mankiw, Gregory. 2018. Principles of Economics: An Asia Edition Vol. 2 Terj. Biro Bahasa Alkemis Pengantar Ekonomi Makro. Jakarta Selatan: Salemba Empat.

Mardani. 2012. Fiqh Ekonomi Syariah: Fiqh Muamalah Cet. 1. Jakarta: Kencana.

Nasution, Mustafa Edwin, dkk. 2006. Pengenalan Ekslusif: Ekonomi Islam. Jakarta: Prenadamedia Group.

Nursyamsiah, Tita. "Krisis Ekonomi dari Prespektif Siyasah Syariyyah". https://www.republika.co.id/berita/koran/iqtishodia/14/o9/25/ncfxw820-krisisekonomi-dari-perspektif-siyasah-syariyyah diakses pada tanggal 22 November 2018.

Ramdansyah, Abdul Aziz. 2016. "Esensi Utang dalam Konsep Ekonomi Islam". STAIN KUDUS: Jurnal Bisnis dan Manajemen Islam. Vol. 4 No. 1.

Tohiri. 2013. Metode Penelitian Kualitatif dalam Pendidikan dan Dan Bimbingan Konseling: Pendekatan Praktis untuk Peneliti Pemula dan Dilengkapi dengan Contoh Transkip Hasil Wawancara serta Model Penyajian Data Ed. 1 Cet. 3. Jakarta: Rajawali Pers.

Triyuwono, Iwan. 2007. "Mengangkat "Sing Liyan" Untuk Formulasi Nilai Tambah Syari'ah", Simposium Nasional Akutansi $X$.

Purwitasari, Fadilla, dan Anis Chariri. “Analisis Pelaporan Corporate Social Responsibility Perbankan Syariah Dalam Perspektif Shariah Enterprise Theory: Studi Kasus Pada Laporan Tahunan Bank Syariah Mandiri Dan Bank Muamalat Indonesia”. Didownload melalui Eprints. Undip. Ac. Id /32102/.

Yahya, Muchlis, dan Edi Yusuf Agunggunanto. 2011. "Teori Bagi Hasil (Profit and Loss Sharing) dan Perbankan Syariah dalam Ekonomi Syariah”. Jurnal Dinamika Ekonomi Pembangunan. Vol. 1 No. 1.

Yusuf, A. Muri. 2014. Metode Penelitian: Kuantitatif, Kualitatif, dan Penelitian Gabungan Ed. 1 Cet. 1. Jakarta: Prenadamedia Group.

Zainuddin Ali, Zainuddin. 2010. Hukum Perbankan Syariah. Jakarta: Sinar Grafika. 
Mengungkap Aspek Sedekah dalam Transaksi Mangpaindan Doi

Pada Masyarakat Lunjen Enrekang

Andi Suwandi Putra Suaib, Wahyuddin Abdullah, Muslimin Kara

DOI : $\operatorname{xxxxxxx}$ 